\title{
Multiple epiphyseal dysplasia type 4
}

INSERM

\section{Source}

INSERM. (1999). Orphanet: an online rare disease and orphan drug data base. Multiple epiphyseal dysplasia type 4. ORPHA:93307

Multiple epiphyseal dysplasia type 4 is a multiple epiphyseal dysplasia with a late-childhood onset, characterized by joint pain involving hips, knees, wrists, and fingers with occasional limitation of joint movements, deformity of hands, feet, and knees (club foot, clinodactyly, brachydactyly), scoliosis and slightly reduced adult height. Radiographs display flat epiphyses with early arthritis of the hip, and double-layered patella. Multiple epiphyseal dysplasia type 4 follows an autosomal recessive mode of transmission. The disease is allelic to diastrophic dwarfism, atelosteogenesis type 2 and achondrogenesis type $1 \mathrm{~B}$ with whom it forms a clinical continuum. 